If, however, there are important sections of industry which have still to learn that, while scientific research cannot provide a ready-made solution of our present industrial difficulties, it does point the road along which persevering effort may enable industry to find a way out of those difficulties, it is important to remember that there are accordingly industries the difficulties of which are due less to economic conditions than to neglect of scientific method and research in the past. This is essentially the mark of defective leadership. Such industries are unlikely of themselves to evolve any constructive plans on broad enough lines to serve the national and not merely individual interests and to eliminate the more wasteful forms of com- petition and overlapping. The scientific planning, which Capt. Macmillan and his followers see as a logical necessity under a tariff policy, cannot be expected of them, and there is, on the contrary, the danger that protection will be used by industries of this type to bolster up the inefficiency of the past. There is every reason to insist that protection should only be afforded to these industries on the understanding that they definitely put their house in order and re-orientate their attitude to fundamental research. They must undertake to carry out investigations designed to yield a reserve of fundamental knowledge which can equally assist in tiding over bad times and in strengthening the industry to meet independently competition from abroad.

\title{
The Electrification of British Railways
}

THE International Electrical Congress was 1 opened at the Sorbonne, Paris, on July 5. More than a thousand delegates representing thirty-one countries attended it. There were several papers on electric railway engineering, most of which discussed the history of electric traction and the modern practice of using direct current at 3000 volts on the railway side of the substations. A paper by Sir Philip Dawson discussed the electrification of British railways.

Sir Philip pointed out that two factors have notably influenced the development of electric traction on British railways The first and most important was the grouping of numerous small railways into four large companies which took place shortly after the War. The Southern Railway serves the south-east and south-west of England, the track being equivalent to 4000 miles of single-line railway. This figure does not include the lengths required for sidings and for garaging railway earriages. The Great Western Railway serves Wales and the west of England, and if we neglect a few small Welsh railways, was practically unchanged by the grouping. The equivalent track length is about 6550 miles. The London, Midland and Scottish Railway serves the west side of the country from London to the north, the equivalent itinerary of track being 13,600 miles. The London and North Eastern Railway serves the north-east of England and Scotland, the equivalent length of the track being 7100 miles.

Many of the companies which were absorbed by these groups were pioneers of electrification and were eager to extend the electrified portions of their lines. So far back as 1904 the Lancashire and Yorkshire Co. electrified the lines between Liverpool and Southport, and just before the War so also were many lines around Manchester. In 1904 the North Eastern Railway Co. had electrified the suburban lines around Newcastle. The London, Brighton and South Coast Railway bad very ambitious schemes for electrifying its lines, and the South Eastern and Chatham Railway had actually passed the contracts for electrifying all its suburban services. In several cases the 'grouping' greatly altered the policy of the original companies.
On railway lines where the traffic is heavy or where the gradients are steep, electrification has many advantages. In industrial districts where the density of the population is great, electric railways are particularly useful. These regions generally follow coal seams. In Scotland, for example, there is one from the east to the west between the Clyde and the Forth To electrify the line between Glasgow and Edinburgh would be a very promising project. In the north of England there are many large coal mines extending through Durham to Cumberland, the coal area covering a space about fifty miles long and twenty miles broad. There are isolated coal mines in other districts, and there is a coal district in South Wales having a length from east to west of about seventeen miles and a breadth of about twenty miles. Leaving the towns out of account, the density of the population varies between 500 to 1000 inhabitants per square mile. No region of the world can compare with Greater London, which within an area of about 460 square miles contains a population of 12 million inhabitants-a population which is greater than a quarter of the total population of Great Britain, more than half that of Belgium, and equal to three times that of Switzerland.

The Southern Railway has little mineral traffic. It serves all the country south of the Thames and depends largely on its local traffic. The Great Western Railway has important mineral and goods traffic. It serves the south of Wales and the tin mines of Cornwall. The London, Midland and Scottish Railway serves Scotland and the Midlands of Lancashire and Yorkshire. It serves the important ports of Liverpool and Glasgow. The London and North Eastern Railway traverses the great industrial regions in the north of England and in Scotland. In these four railways the receipts from the mineral and merchandise traffic are $25,57,59$, and 64 per cent of the total traffic receipts respectively.

The other important factor affecting the use of electric traction in railways was brought into existence when the Act of Parliament of 1926 created the Central Electricity Board to control the production ' in bulk' of the electricity generated in Great 
Britain. The grid now practically joins up all the ' effective' generating stations. The overhead lines are roughly parallel to many of the main railways.

The Southern Railway inherited from the London, Brighton and South Coast Railway a very flourishing suburban electrified system. Had not the grouping altered matters, it was the intention of the directors not only to finish the electrification of all their suburban systems, but also to work. electrically the whole of the main lines as far as Worthing, Brighton, Eastbourne, and Hastings. Taking into account the fact that most of the lines were actuated by direct current, the Southern Railway adopted the d.c. system as the standard. It is still engaged in electrifying the passenger lines from London to Brighton and Worthing on this system. Its electrical lines at present are equivalent to about 750 miles of single track, besides the mileage required for side tracks, garaging purposes, etc. It possesses no electric locomotives, using 881 electrified motor carriages. Only a few miles of the Great Western Railway are electrified. The London, Midland and Scottish Railway has electrified the lines between Liverpool and Southport, Lancaster and Morecambe Bay, and Old Broad Street to Watford. The London and North Eastern Railway has only electrified a suburban section at Newcastle and a goods line in the neighbourhood of Sunderland, from Newport to Shildon. On the Newport line, electric locomotives are used. There are also several lines of purely local interest such as the Underground Railways of London.

The Weir Commission was appointed by the last Government to examine the economic and other aspects of the problem of electrifying the main railway lines of Great Britain. The report was published in March of last year, and confirmed the views of those engineers who held that electrifi cation would lead to important economies and would be a boon to the country. The working results obtained by several electric railways in other countries also support this conclusion. In France particularly the electrification of the main lines has been very beneficial. It is pointed out that although Great Britain was the pioneer of steam railways it lags behind several other countries in electrifying its railways.

Sir Philip Dawson has made special studies of the main lines of the London, Brighton and South Coast Railway and of a project for electrifying the greater part of the main lines of the Great Western Railway. He finds that for slow goods trains the mean velocity is increased 30 per cent by using electric traction, and that for ordinary passenger trains the mean speed can be increased 25 per cent. The cost of repairs, renewals, and upkeep of locomotives is approximately 40 per cent of that of steam railways. This agrees closely with the estimates made by other engineers. Adding together the total capital required for electrifying all the railways in Great Britain, the economies directly attributable to this change would show a gain of 7-10 per cent upon the capital employed.

The quantity of energy necessary to supply a railway depends on local conditions and on the "ton miles" required by different kinds of trains. A rough estimate can be made of the cost by examining the corresponding costs of electric railways abroad. Taking this as a basis and assuming the average cost of the ton mile on British railways, it is estimated that the 'maximum demand' for direct current from the railway substations would be of the order of 1.5 million kilowatts. To get the average load the mean factor is assumed to be 0.5 . Hence the annual consumption on the d.c. side of the railway substations would be about 6500 million kilowatt hours a year.

If the electrification of the railways of Great Britain were begun at once, it would be finished by 1950 . Assuming that the expected load on the 'grid' at that date is realised, the demand of the railways would be a fifth of the total output from the grid. The maximum of the railway demand from the grid would be about ten per cent of the total demand. To convert the standard three-phase a.c. supply into direct current, mercury rectifiers would probably be employed. Assuming that this is done, the efficiency of the conversion would be 84 per cent. Estimating that the cost of a kilowatt hour at the generating station would be $0 \cdot 25 d$, the cost for the d.c. unit supplied to the railway would be $0 \cdot 495 d$. This compares excellently with the $0.5 d$. unit given in the Weir Report. Adding on the cost of operating the substations, we find that the total cost would be $0.55 d$.

The regular supply of energy taken by the electrified railways from the grid would react most favourably by lowering the general price of electricity. The electrification would necessitate the construction of about ten new power stations, for which the cost would be appreciably less than that of existing stations, thus contributing to the general lowering of the price of electricity. 'The necessary great increase in the number of substations would make it possible to supply electricity economically for general purposes to new areas. It will be seen that the conclusions Sir Philip Dawson draws will encourage railway engineers to proceed with their electrification schemes.

\section{Obituary}

Prof. Graham Lusk, For.Mem.R.S.

$\Delta \mathrm{N}$ investigator whose enthusiasm in the purA suit of knowledge never waned; a man who never wavered from the high standards of work and conduct which he set for himself in youth, and whose qualities of mind and heart endeared him to all; a teacher who always gave of his best: such was Graham Lusk. As such he will be greatly missed in many centres by a multitude of colleagues, friends, and pupils. From the beginning of his adult life to its end-for more than forty years-he devoted himself to the study of the problems of

No. 3278, Vor. 130] 